STANISŁAW CHROBAK

Wydział Nauk Pedagogicznych

Uniwersytet Kardynała Stefana Wyszyńskiego

Warszawa

ORCID ID: http://orcid.org/oooo-0003-3015-4580
Forum Pedagogiczne

9(2019) 2, cz. 1

Wpłynęło: 4.03.2019 Zatwierdzono do druku: 26.06.2019 DOI: $10.21697 / f p .2019 .2 .18$

\title{
THE UNIVERSITY - A SPACE FOR BUILDING COMMUNITY AND TRUST
}

\begin{abstract}
The University is constantly subject to a process of intense transformations. The diversity of social needs and expectations towards university education requires that the academic community analyze its current status, future challenges and consider initiatives that address these challenges. Thus, emphasizing the significance of universitas, as a community of teaching and learning (universitas studiorum et studentium), it is worth investigating how to build this community without losing fundamental values in massive studies. The university fulfills its own purpose when in a specific community that employs scientific creativity and research, it leads a person to development of their versatile spiritual potential of mind, will, heart, and a formation of the whole person.
\end{abstract}

Keywords: person; truth; university; community; trust.

\section{Introduction}

Universities occupy a unique place in the history of culture and civilization. Universitas means "general", "universality", "all", "whole", "commonality." According to Władysław Stróżewski (1992, pp. 8-9), equally important is another understanding of universitas as the aggregate of sciences and skills, or at least a selection that allows one to see a special unity in them. The Magna Charta Universitatum (1988), signed by the provosts of the European universities in Bologna during the celebrations of the nine hundredth anniversary of the oldest university in Europe, states that the university is an autonomous institution that plays a fundamental role in the development of societies by creating, researching, evaluating and conveying culture through scientific and didactic activity. It stresses that instruction and research at universities must be inextricably linked and that the freedom to conduct research and education is the most fundamental principle of university life. The University, as stressed in this document, is also a trustee 
of the European humanistic tradition that constantly strives to attain universal knowledge and fulfils the essential need for different cultures to know and influence one another.

The University continuously undergoes intense transformations. The diversity of social needs and expectations towards university education requires that the academic community analyze its current status, future challenges and consider initiatives that address these challenges. In a natural way, the University can become a home and a place of prosperity for arts and science, but also because of goodness it can become the guardian of all values derived from goodness. Thus, emphasizing the significance of universitas as a community of teaching and learning, universitas studiorum et studentium, it is worth understanding how to build this community without losing fundamental values in egalitarian studies open for all. The academia should provide opportunities for sharing experience and experiencing the community.

\section{The University - the identity and the search for truth}

The University is one of the largest and most sustainable products of European culture. It has been a special institution entrusted with an extremely responsible task of maintaining continuity and transmitting culture, a mission that cannot be successfully carried out without faith in culture and the certainty that it is worth preserving it. The University has contributed to the fundamental changes in the way science is practiced and has served to shift from the study of individual sages and scholars to scientific work carried out by a group of professionals trained to perform this function. It was the center of open teaching. It covered areas of knowledge reserved for the Church such as theology and canon law, as well as secular areas of life, through educating physicians, officials or dealing with natural sciences and linguistics. Its unique position was associated not only with the specification of tradition, but also due to the particular status of knowledge, not only with the practical face, but mainly the pure one, and with conducting research and recording its effects, and also because of merging into one harmonious organization of people involved in different disciplines of science (Antonowicz, 2005, pp. 21-28).

The University is a work of the Middle Ages, born off its vision of Man, Nature and God. Something as special, as original in the history of civilization as for example Gregorian chant or polyphonic music. All great civilizations have their liturgy and their cathedrals, their saints and their gospels. They all know what is holy and what is pious. All give evidence of a creative sense in the field of art, thought and spirituality. But only one European medieval culture has created universities, from Bologna to Krakow, from Paris to Toledo, from Oxford to Uppsala. (Moulin, 2002, p. 7)

The University is one of the few institutions originating from medieval Europe which has not lost its attractiveness. It is still alive and it has preserved the basic 
message underlying the establishment of a research and teaching institution. It combines two properties at the same time. On the one hand it is an exceptional attachment to traditional forms of science organization and education, preservation of customs, freedom of research and education, selection of candidates for students and teaching roles. On the other hand, it is synonymous with modernity, discovering the laws of nature, generating new knowledge, civilization progress, attitudes that are creative and open to the reality of scholar community. But the university is also changing (Górniewicz \& Piotrowski, 2014, pp. 10-11). The University is becoming an institution of a new kind.

Most projects for the University of the twenty-first century bear a striking resemblance to the University projects of the nineteenth century. The reason we should reread Humboldt, Schiller, Schleiermacher, Fichte and Kant is that the vast majority of contemporary "solutions" to the crisis of the University is in fact no more than restatements of Humboldt or Newman whose apparent aptness is the product of ignorance of these founding texts on the history of the institution. (Readings, 1999, p. 62)

The challenges faced by the University today concern various areas and are the result of changes taking place in the environment in which it operates. The University with its scholars, students, and administrators must face new challenges. The identity crisis of the University is built into the identity crisis of modern man. Its sources can be found in various areas of human activity. It is the University that is particularly predisposed to develop a reflective view of the world, to help in discovering and implementing universal spiritual values, which would allow the promotion of the idea of shaping history and the human being embedded in it in a rational way (Semków, 2003, pp. 46-49).

Searching for the truth about the world and a man, searching for answers to the questions people always pose, seems to be the ground for meeting various fields of science and creating a real universitas. So "What is the university? What is its task? [...] I think one could say that at the most intimate level, the true origin of the university lies in the thirst for knowledge that is proper to man. The human being wants to know what everything around him is. He wants truth" (Benedykt XVI, 2008, p. 13-14). The search for truth is the mission of every field of science, and it always acts as a servant to man. It is also confirmed by Agnieszka Lekka-Kowalik (2006, p. 162): "Truth as a value is an element that defines the University, differentia specifica, allowing to distinguish the University from other institutions, including other educational institutions, geared towards completing specific social tasks."

Participating in truth liberates man and strengthens him in his dignity. Man becomes himself through the truth, he learns truth about himself and his freedom. The assignment to the truth is manifested through freedom, responsibility and duty, which constitute a real and concrete matrix of the personal life of man both in thinking and in actions. Exploring truth introduces the rich world of the relationship between truth and good. Thus, according to Benedict XVI (2007, pp. 12-13): 
Every university must always preserve the traits of a study centre "within man's reach", where the student is preserved from anonymity and can cultivate a fertile dialogue with his teachers from which he draws an incentive for his cultural and human growth. [...] Naturally, and also rightly, the disciplines tend to specialization, while what the person needs is unity and synthesis. Secondly, it is fundamentally important that the commitment to scientific research be open to the existential question of meaning for the person's life itself. Research seeks knowledge, whereas the person also needs wisdom, that knowledge, as it were, which is expressed in the "knowing-living." In the third place, only in appreciating the person and interpersonal relationships can the didactic relationship become an educational relationship, a process of human development.

Knowing the truth is the only of its kind gaudium veritatis (spiritual joy). Neglecting this dimension of science and limiting attention to its purely utilitarian aspects is a threat not only for science but directly for man and for society.

\section{Ethos of a scientist}

In its initial assumption, the University was to be primarily a group of people connected by a common conviction about the value of knowledge, science and education as a form of intellectual discovery of the world. Fulfilling its calling in a particular place and time is a bridge that spans both the past and the future. It is a natural place for the emergence and development of sciences that combine various areas and methods of research.

The University is a koinonia - a community of values and goals. The keystone of the axionormative order of this community is truth, the primary good being the ideal motivating the cognitive pursuits of scholars. [...] University koinonia consists of people participating in the pursuit of scientific truth within various areas of substantive competence that have a common "problem situation" and, consequently, a common network of scientific communications, a common preference of aspects of cognitive interest objects (what is the subject of the view in relation to imaging), as well as common rules and patterns of cooperation shaping their lifestyle in the exploration, discussion and education of adepts. (Goćkowski, 1998, pp. 22-23)

The character of the tradition of academic life depends primarily on the style of scientific work of the professional staff. There is no university tradition without the ethos of a scientist and rites and ceremonies that make sense in connection with the ethos.

Man, to live, develop and be himself, also needs 'ethos'. But the 'ethos' of man is unique. [...] Man is inherently an ethical being, that is, someone for whom the problem of "ethos" is also the problem of his own being. If he discovers where, among what matters, with whom his "ethos" is connected, he can "bear 
much fruit." If he does not find it, he will live like a being, alien to himself.

(Tischner, 1984, p. 56)

Therefore, in the tradition of academic life, there are three important questions that need to be answered: 1 ) what rules of the game about the scientific truth are passed on in the relay of generations of academic staff ?; 2) who and how communicates those rules?; and finally 3 ) how is the matter of continuity and change of such rules understood and treated? (Goćkowski \& Woźniak, 2003, pp. 128-129).

The human ethos is in its most fascinating version a creative ethos, not an imitative one. „Truth, justice, faithfulness, honesty, generosity are all values through which man refers to man. It seems that some invisible force controls human life. Following its appeals, man seems to gradually find his 'ethos."' (Tischner, 1984, p. 57) At the root of the human ethos there is "self-creation" through doing. Man is not only the perpetrator of his actions, but he is also their creator. Man needs his ethos to be himself. In this sense, ethos is not just a habit of being together, but it is lightened up by reason, chosen by our own education, it is a way of life. Therefore, transferring, teaching and representing certain values make up a basic element. "The education of a capable man prepared to take on social roles in the market remains in the interest of the state, students and university." (Kościelniak, 2015, p. 29) A man responsible for his continuous development can and should employ his personal thought to reach the truth, select and judge.

Ethos is seen as typical attitudes in a given group of people and a constant way of being, behaving. It points to "the true recognition and practice of moral obligation." It is an external expression of accepted ethical norms and their simplest life test. As emphasized by Janusz Goćkowski (1998, p. 27):

The presence of a university scholar in the world of people of science (the first area where expectations and requirements regarding the behavior of a researcher are defined come from) is the presence of a participant in the pursuit of scientific truth observing and respecting ethical norms and etiquette. The presence of a university scholar in a national community is a presence in the community of people shaping the character of a nation's culture life. It is the presence of a person who wants and can play the role of someone from the "mental aristocracy" of the national community - who creates and teaches for the sake oflasting and development in the identity of this community.

The University has never worked in a vacuum. It belongs to the world of science and a scholar cannot be set free from the rigors of academic work. Where a professor was a master not only formally, he managed to overcome the burden of the era. Therefore, a university professor unlike a professor of any other higher education institution, should have a profile of a specialist (that appears necessary in the era of specialization in science), but also have a mental class that allows being included among the intellectuals of a given society. Education of academic staff does not only entail instructions in research methods, but also the ethos of science. These two 
matters cannot be separated from each other, and the master-student relationship is a fundamental one (Salmonowicz, 1998, pp. 55-60). Thus, for example:

the basic assumption of von Humboldt's strategy with respect to academic scholars was the inseparability of research and teaching (Einheit von Forschung und Lehre), which was to guarantee the best quality and currency of knowledge. The second assumption was the famous postulate to provide university employees with solitude and freedom (Einsamkeit und Freiheit), i.e. a guarantee of independence of individual researchers who, without restraint and cooperating without a predetermined goal and without coercion, would gain a higher level of scientific knowledge. According to von Humboldt, science has its own rhythm, and everyone who practices it has other abilities that cannot be developed by force. At the same time, however, every researcher needs complementation by others, so the cooperation of many individuals serves both science and the individual scholars. (Musiał, 2013, pp. 313-314)

It needs to be stressed that the term 'being creative' in this particular context, refers to taking action, working and spending free time together, ie in a community of the master and his disciple, where each participant shapes up their own identity.

\section{The University - trust and concern for being in the community}

B. Readings (1999, p. 20) claimed that the University "becomes one site among others where the question of being-together is raised." In the universitas understood as a community, we can find the axiological sensitivity of the students, where the experience of life, stands next to a fresh look, and the calm contemplation of the truth coexists with the anxiety of the search for the truth. The educational community is created thanks to the individuality and uniqueness of academic teachers and students cooperating with each other. University people raise one another - not through special lectures or "form period", but through conscious participation in what they ultimately serve (Stróżewski, 1992, pp. 23-24). Thus, "every university has an inherent community vocation: indeed, it is, precisely, a universitas, a community of teachers and students committed to seeking the truth and to acquiring superior cultural and professional skills. The centrality of the person and the communal dimension are two fundamental poles for an effective structuring of the universitas studiorum." (Benedykt XVI, 2007, p. 12)

The traditional academic culture puts its trust in the academic staff based on the assumption that the professional ethos of the professor commits to decent scientific and didactic work. The strength of the culture of trust was the incorporation of mechanisms of academic self-control in the activity of the University. The professor felt obliged in the area of didactics to teach quality classes, set requirements for students, supervise and advise to younger employees, and participate in the creation of curricula. In the scientific sphere, the need to conduct and publish research was associated with the pursuit of scholarly advancement, 
and at the same time it was inspired by internal motivations. In practice, only some of the faculty conducted research, the rest focused on instruction. The academic work system was also marked by collegiality and focus on teamwork, which often led to slowing down the decision-making mechanisms, but gave the academic staff a sense of participation and involvement in the functioning of the university. Over the years many cultural-social and economic factors have led to the disassembly of the traditional university model and the disappearance of trust culture patterns. A change in the university ethos is associated with the assimilation of specific "rites of transition" from a culture of trust and academic ethics to a culture of proof, audit, control or evaluation (Sułkowski, 2016, pp. 25-27) ${ }^{1}$. It is worth noting that university education is a meeting of a man with a man who share common ideas and common explorations. Only then is there a chance to create scientific schools, which will be not only a formal grouping of related disciplines, but also a community of people who are connected by the search for truth within a given scientific field and the commonly adopted style and method of this search and the value system that accompanies it. (Przecławska, 1998, p. 162)

Science makes sense and is valid when it is deemed capable of discovering the truth and when the good of man is recognized in the truth. In serving the truth, science serves man, in defending the truth, it defends man in what is most important to him.

Human perfection, then, consists not simply in acquiring an abstract knowledge of the truth, but in a dynamic relationship of faithful self-giving to others. It is in this faithful self-giving that a person finds a fullness of certainty and security. At the same time, however, knowledge through belief, grounded as it is on trust between persons, is linked to truth: in the act of believing, men and women entrust themselves to the truth which the other declares to them. (Jan Pawel II, 1998, p. 32)

This requires, among other things, a dialogue and the existence of an authentic community of researchers who, along with a family community, constitute a real community of people, a community of those who seek the truth and strive for knowledge. All this can and should be used in building university wisdom. So the "between" of the university is a reflection on the position of man, but it is also the joy of being together, which means that no place is exclusively "mine", because the place really happens only "between." [...] the university serves the world not by unity, but by the multiplicity manifested in the multitude of scientific disciplines as well as views on reality, represented by individuals connected with the university. (Sławek, 2009, p. 25)

1 Trust „is based on three pillars: (a) a credibility assessment that leads to calculated, cognitive or strategic trust, (b) a personal confidence impulse, and (c) a culture of trust: widespread in the community, shared and containing normative expectation to trust others and to be credible yourself." (Sztompka, 2007, p. 368) 
With an increasing significance of the role of science in modern civilization, there is a need for a deep reflection on man. New questions formulated in contact with scientific discoveries lead to issues relevant to the philosophy of life.

The University fulfills its own purpose when, being in a specific community of people and with the help of scientific creative and research tools, it leads to the fact that a person develops and his or her versatile spiritual potential is released. The potential of mind, will, heart; formation of the whole person. [...] The University is a battle front for humanity. Humans will not benefit from it, only because it is called university. Yes, you can produce a bad expression, or a brutal expression. You can create a series of trained, educated people, but the problem is whether you liberated the enormous spiritual potential of a man through which a human actualizes his humanity. (Jan Paweł II, 2010, pp. 173-174)

It is about enabling students to reflect on essential matters. Showing the sense of being man, the structure of his existence and personality, the essential conditions of human activity, human freedom and interpersonal communication, the rational basis of human life in general, is for scientific work of the University an indispensable prerequisite of the sense of scientific life.

\section{Conclusion}

Talking about "university life of ideas" can be considered absurd; it can be seen as an unjustified attachment to the world that does not exist and as a retreat from reality led by the rules of the market game. By serving the truth, the University serves man. Ideas grow and set things into motion. They cannot be born by force, but they grow in man who works methodically. There are books, lectures, meetings, conversations that have not taught us anything but they are intellectual events that are long remembered, events that change us permanently. We are not talking about some grotesque solemnity as a response to existential questions from the students. It is all about the atmosphere of friendliness which allows them to address these issues not only individually in the silence of their hearts but also in a community or in various university communities (Gutowski, 2005, pp. 47-49; Murawska, 2018, pp. 124-125). Bill Readings (1999, pp. 192-193) says, "a major shift in the role and function of the intellectual is occurring is clear. What it will come to have meant is an issue upon which those in the University should attempt to have an impact. An attention to this problem is necessary." 


\section{References}

Antonowicz, D. (2005). Uniwersytet przyszłości. Wyzwania i modele polityki. Warszawa: Instytut Spraw Publicznych.

Benedykt XVI. (2007). Niech św. Augustyn będzie dla nas wzorem dialogu wiary i rozumu. Spotkanie ze wspólnotą akademicką na dziedzińcu uniwersytetu. L'Osservatore Romano. Wydanie polskie, 6(294), 12-14.

Benedict XVI. (2008). The Truth Makes Us Good and Goodness Is True. Retrieved from: https://w2.vatican.va/content/benedict-xvi/en/speeches/2008/january/ documents/hf_ben-xvi_spe_20o80117_la-sapienza.html.

Goćkowski, J., Woźniak, A. (2003). Tożsamość i żywotność uniwersytetu. Problem charakteru tradycji życia akademickiego. In A. Ładyżyński \& J. Raińczuk (Eds.). Uniwersytet - między tradycją a wyzwaniami wspótczesności (pp. 121-148). Kraków: Oficyna Wydawnicza „Impuls”.

Goćkowski, J. (1998). Funkcjonalność uniwersytetu w perspektywie długiego trwania. In H. Żytkowicz (Ed.). Idea uniwersytetu u schyłku tysiąclecia (pp. 21-48). Warszawa: Wydawnictwo Naukowe Scholar.

Górniewicz, J., Piotrowski, P. (2014). Uniwersytet jako źródło wartości kultury. Olsztyn: Pracownia Wydawnicza EISet.

Gutowski, P. (2005). Katolickie uniwersytety a ideał pełnej prawdy. Znak, 606(11), $43-57$.

John Paul II. (1998). Encyclical letter Fides et ratio. Retrieved from: http://w2.vatican. va/content/john-paul-ii/en/encyclicals/documents/hf_jp-ii_enc_14091998_fides-et-ratio.html.

Jan Paweł II. (2010). Przemówienie do profesorów i studentów Katolickiego Uniwersytetu Lubelskiego. Częstochowa, 6 czerwca 1979 r. In A. Sujka (Ed.). Gaude Mater Polonia. Pierwsza pielgrzymka, czerwiec 1979 r. (pp. 173-176). Kraków: Wydawnictwo M.

Kościelniak, C. (2015). Uniwersytet, rozwój, kultura. Poznań: Wydawnictwo Naukowe UAM.

Lekka-Kowalik, A. (2006). O dostojeństwie uniwersytetu - raz jeszcze. Ethos, 3(75), 162-174.

Magna Charta Universitatum, Bologna, Italy September 18, 1988. Retrieved from: http://www.aic.lv/bolona/Bologna/maindoc/magna_carta_univ_.pdf

Moulin, L. (2002). Średniowieczni szkolarze i ich mistrzowie. Gdańsk-Warszawa: Wydawnictwo Marabut.

Murawska, A. (2018). Uniwersytet jako przestrzeń życia w ideach. Rocznik Lubuski, 44(2), 119-127.

Musiał, K. (2013). Uniwersytet na miare swego czasu. Transformacja społeczna $w$ dobie postindustrialnej a zmiany w szkolnictwie wyższym krajów nordyckich. Gdańsk: Wydawnictwo słowo/obraz terytoria. 
Przecławska, A. (1998). Uprawianie nauki istotą kształcenia uniwersyteckiego. In H. Żytkowicz (Ed.). Idea uniwersytetu u schytku tysiąclecia (pp. 161-162). Warszawa: Wydawnictwo Naukowe Scholar.

Readings, B. (1999). The University in Ruins. London: Harvard University Press.

Salmonowicz, S. (1998). Między hierarchicznością, feudalizmem a brakiem dobrych obyczajów w nauce. In H. Żytkowicz (Ed.). Idea uniwersytetu u schyłku tysiąclecia (pp. 53-61). Warszawa: Wydawnictwo Naukowe Scholar.

Semków, J. (2003). Tożsamość uniwersytetu wobec kryzysu wartości świata ponowoczesnego. In A. Ładyżyński \& J. Raińczuk (Eds.). Uniwersytet - między tradycją a wyzwaniami wspótczesności (pp. 45-52). Kraków: Oficyna Wydawnicza „Impuls".

Sławek, T. (2009). Uniwersytet i to, co między ludźmi. Nauka, 2, 23-36.

Stróżewski, W. (1992). W kręgu wartości. Kraków: Wydawnictwo Znak.

Sułkowski, Ł. (2016). Kultura akademicka. Koniec utopii? Warszawa: Wydawnictwo Naukowe PWN.

Sztompka, P. (2007). Zaufanie. Fundament społeczeństwa. Kraków: Wydawnictwo Znak.

Tischner, J. (1984). Etyka wartości i nadziei. In D. von Hildebrand, J.A. Kłoczowski, J. Paściak, \& J. Tischner (Eds.). Wobec wartości (pp. 55-149). Poznań: Wydawnictwo „W drodze”.

\section{UNIWERSYTET - PRZESTRZEŃ BUDOWANIA WSPÓLNOTY I ZAUFANIA}

Streszczenie: Uniwersytet nieustannie podlega procesowi intensywnych przeobrażeń. Różnorodność potrzeb i oczekiwań społecznych wobec kształcenia uniwersyteckiego wymaga, aby społeczność akademicka poddała analizie swój aktualny status, wyzwania przyszłości i rozważyła inicjatywy odpowiadające tym wyzwaniom. Podkreślając zatem to znaczenie universitas, wedle którego jest on wspólnotą nauczających i uczących się: universitas studiorum et studentium, warto postawić pytanie w jaki sposób budować tę wspólnotę, aby w masowych w swym charakterze studiach nie zagubić fundamentalnych wartości. Uniwersytet wtedy spełnia swój własny cel, gdy w określonej wspólnocie ludzi, przy pomocy środków o charakterze naukowo-twórczym, naukowo-badawczym prowadzi do tego, że rozwija się człowiek, że się wyzwala jego wszechstronny potencjał duchowy. Potencjał umysłu, woli, serca; formacja całego człowieka.

Słowa kluczowe: osoba; prawda; uniwersytet; wspólnota; zaufanie.

Stanisław Chrobak - doktor habilitowany, profesor nadzwyczajny UKSW, kierownik Katedry Pedagogiki Przedszkolnej i Wczesnoszkolnej na Wydziale Nauk Pedagogicznych Uniwersytetu Kardynała Stefana Wyszyńskiego w Warszawie. W swoich badaniach podejmuje problematykę z zakresu pedagogiki ogólnej, teoretycznych podstaw wychowania, 
filozofii wychowania i pedagogiki o inspiracji chrześcijańskiej. Jest członkiem Zespołu Pedagogiki Chrześcijańskiej KNP PAN, Towarzystwa Naukowego Franciszka Salezego oraz Zespołu Teorii Wychowania KNP PAN. Autor m.in. takich książek, jak: Koncepcja wychowania personalistycznego w nauczaniu Karola Wojtyly - Jana Pawła II (Warszawa 1999), Podstawy pedagogiki nadziei. Współczesne konteksty w inspiracji personalistyczno-chrześcijańskiej (2009), Ksiądz Bosko w wypowiedziach papieży, cz. 1 (Warszawa 2014), Ksiądz Bosko w wypowiedziach papieży, cz. 2 (Warszawa 2015) oraz ponad 100 artykułów. Adres korespondencyjny: Wydział Nauk Pedagogicznych UKSW, ul. Wóycickiego 1/3, budynek 15, 01-938 Warszawa. Adres e-mailowy: s.chrobak@uksw.edu.pl. 